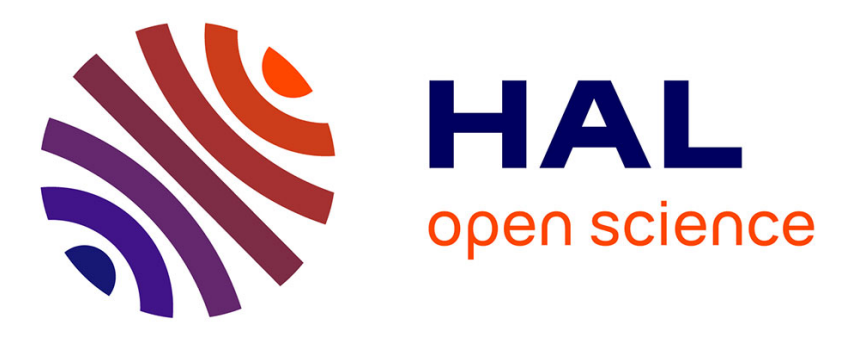

\title{
Synthesis, characterization and use of a POSS-arylamine based push-pull octamer
}

Pablo Simón Marqués, José María Andrés Castán, Amir Hossein Habibi, Sylvie Dabos-Seignon, Sébastien Richeter, Ahmad Mehdi, Sébastien Clément, Philippe Blanchard, Clément Cabanetos

\section{To cite this version:}

Pablo Simón Marqués, José María Andrés Castán, Amir Hossein Habibi, Sylvie Dabos-Seignon, Sébastien Richeter, et al.. Synthesis, characterization and use of a POSS-arylamine based pushpull octamer. New Journal of Chemistry, 2021, 45 (14), pp.6186-6191. 10.1039/D1NJ00732G . hal03389382

\section{HAL Id: hal-03389382 \\ https://hal.science/hal-03389382}

Submitted on 21 Oct 2021

HAL is a multi-disciplinary open access archive for the deposit and dissemination of scientific research documents, whether they are published or not. The documents may come from teaching and research institutions in France or abroad, or from public or private research centers.
L'archive ouverte pluridisciplinaire HAL, est destinée au dépôt et à la diffusion de documents scientifiques de niveau recherche, publiés ou non, émanant des établissements d'enseignement et de recherche français ou étrangers, des laboratoires publics ou privés. 


\title{
Synthesis, Characterization and use of a POSS-Arylamine Based Push-Pull Octamer
}

\author{
Pablo Simón Marqués, ${ }^{a}$ José María Andrés Castán, ${ }^{a}$ Sylvie Dabos-Seignon, ${ }^{a}$ Sébastien \\ Richeter, ${ }^{\mathrm{b}}$ Ahmad Mehdi, ${ }^{\mathrm{b}}$ Sébastien Clément, ${ }^{\mathrm{b}^{*}}$ Philippe Blanchard, ${ }^{\mathrm{a}^{*}}$ and Clément \\ Cabanetos $^{a^{*}}$ \\ a Univ Angers, CNRS, MOLTECH-Anjou, 49045 Angers, France; \\ b ICGM, Univ Montpellier, CNRS, ENSCM, 34095 Montpellier, France
}

\begin{abstract}
The first synthesis of an original octamer consisting of a central polyhedral oligomeric silsesquioxane (POSS) cage decorated with electro- and optically active arylamine-based push-pull building-blocks is reported herein. Once fully characterized, the potential of the new compound was evaluated as donor material in bulk heterojunction organic solar cells. With promising power conversion efficeincies, good processability and film forming properties, such multimer architectures turns out to be potential candidates to bridge the gap between small molecules and polymers
\end{abstract}

\section{Introduction}

Within the past generation, organic photovoltaics (OPV) has attracted considerable research attention as evidenced by the rapid and constant growth in efficiencies from less than one percent to more than $17 \%$ in single junction organic solar cells (OSCs). ${ }^{1}$ This leap resulted from the synergistic optimization of both the device stack and the nature of the active layer. ${ }^{2}, 3$ Considering that the latter is usually composed of an electron donor blended with an electron acceptor, it turned out that controlling the morphology of this organic thin film is a key parameter to achieve high efficiencies. ${ }^{4,5}$ Therefore, the development of strategies to regulate the self-assembly properties of these photoactive materials through chemical engineering is generally not straightforward and commonly relies on purely empirical trial-and-error processes. Hence, several approaches are usually considered involving the use of solvent additives, post-deposition thermal/solvent annealing and/or the incorporation of nanoparticles. ${ }^{6-8}$

Several studies have reported that incorporating carbon nanotubes or nanoparticles such as silver, gold and silica nanoparticles can improve the morphology of the active layer. ${ }^{9-12}$ Recently, theoretical studies have notably shown that introducing poly(3-hexylthiophene) (P3HT)-grafted silica nanoparticles with appropriate grafting density and molecular weight of P3HT chains can lead to the formation of an active layer with suitable characteristics (crystallinity of P3HT, domain size, elimination of isolated islands of $(6,6)$-phenyl-C61-butyric acid methyl ester (PC $\left.\left.\mathbf{P}_{61} \mathbf{B M}\right)\right)$ and thus, to the improvement of photovoltaic performances. ${ }^{13}$

In this respect, cage-like silsesquioxanes, usually called polyhedral oligomeric silsesquioxanes (POSS), consisting of a silicon-oxygen cubic core with a corona of organic substituents, are promising materials to be integrated in OPV system. ${ }^{14}$ Due to their nanometric size (1 to $3 \mathrm{~nm}$ ), they are often considered as the smallest functionalized silica nanoparticles. ${ }^{15}$ Their migration and aggregation behavior in a matrix can be easily tuned by varying the nature of the organic substituents to obtain the desired nanostructure. ${ }^{16,17}$ For instance, Morgan and collaborators have reported

the positive impact on the phase segregation of a P3HT:PCBM blend by adding specifically tailored polyhedral oligomeric silsesquioxanes (POSS) based nanoparticles. ${ }^{18}$ More recently, Gong et al. have also shown that end-functionalizing $\mathrm{P} 3 \mathrm{HT}$ chains with POSS results in the formation of two-dimensional conjugated polymeric crystals where $\mathrm{P} 3 \mathrm{HT}$ chains are sandwiched between two POSS layers, allowing to improve chargecarrier mobility and the power conversion efficiency (PCE) up of $40 \%$ compared to one-dimensional (1D) P3HT blended with $\mathbf{P C}_{61} \mathbf{B M} .{ }^{19}$ On the other hand, the POSS core can also facilitate the electron injection thus improving the current density of light emitting devices when grafted to semiconducting polymers. ${ }^{20,21}$

Hence and as a step forward, we report herein the decoration of a POSS derivative by an optically active push-pull molecule and the use of this original structure as electron donor material in bulk heterojunction organic solar cells (Figure 1). ${ }^{22}$ We indeed recently showed that multimeric architectures can combine the advantages of both small molecules and polymers, namely a limited batch-to-batch variation due to their well-defined structure and good film forming properties. ${ }^{23}$ 


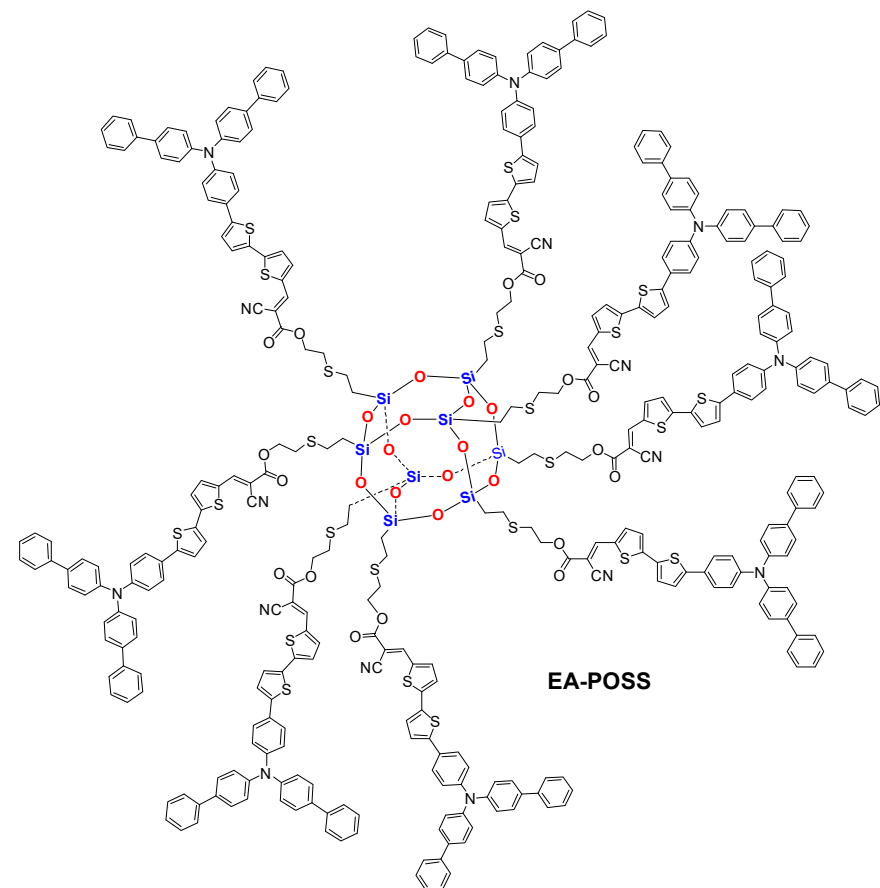

Figure 1. Structure of the push-pull decorated Electro-Active POSS derivative (EA-POSS).

\section{Materials and Methods}

All reagents and chemicals from commercial sources were used without further purification unless specified. Solvents were dried and purified using standard techniques. Octavinyl POSS 1 (97\%) was kindly provided by Sikemia (Montpellier, France). POSS 2 and compound 5 were prepared according to reported methods. ${ }^{22,24}$

Microwave assisted reactions were performed in the cavity of a Biotage Initiator+ system in sealed reactors. Flash chromatography was performed with analytical grade solvents using ALDRICH silica gel (technical grade, pore size $60 \AA$, 230-400 mesh particle size). Flexible plates ALUGRAM Xtra SIL G UV254 from MACHEREY-NAGEL were used for TLC. Compounds were detected by UV irradiation (BIOBLOCK SCIENTIFIC). NMR spectra were recorded either on a BRUKER AVANCE III 300 spectrometer $\left({ }^{1} \mathrm{H}, 300 \mathrm{MHz}\right.$ and $\left.{ }^{13} \mathrm{C}\left\{{ }^{1} \mathrm{H}\right\}, 75 \mathrm{MHz}\right)$ or on a BRUKER AVANCE III $500\left({ }^{1} \mathrm{H}, 500 \mathrm{MHz},{ }^{13} \mathrm{C}\left\{{ }^{1} \mathrm{H}\right\}, 125 \mathrm{MHz}\right.$ and ${ }^{29} \mathrm{Si}\left\{{ }^{1} \mathrm{H}\right\}, 99 \mathrm{MHz}$ ) spectrometer. Chemical shifts in ppm are calibrated to TMS on the basis of the relative chemical shift of the residual non-deuterated solvent as an internal standard and coupling constants $\mathrm{J}$ in $\mathrm{Hz}$. UV-Vis absorption spectra were recorded with a PERKIN ELMER 950 spectrometer. Matrix assisted laser desorption/ionisation time-of-flight (MALDI-ToF) mass spectra were recorded on a Rapiflex TOF/TOF instrument (Bruker, Wissembourg, France). High resolution mass spectrometry (HRMS) was performed with a JEOL JMS-700 B/E or a JEOL SpiralTOF JMS3000. Cyclic voltammetry was performed using a BIOLOGIC SP-150 potentiostat with positive feedback compensation in $0.10 \mathrm{M} \mathrm{Bu}{ }_{4} \mathrm{NPF}_{6} / \mathrm{CH}_{2} \mathrm{Cl}_{2}$ (HPLC grade).
Experiments were carried out in a one-compartment cell equipped with a platinum working electrode $(2 \mathrm{~mm}$ of diameter) and a platinum wire counter electrode. A silver wire in a $0.01 \mathrm{M}$ solution of $\mathrm{AgNO}_{3}$ in $\mathrm{CH}_{3} \mathrm{CN}$ was used as reference electrode. The potentials were then expressed vs. the ferrocene/ferrocenium couple $\left(\mathrm{Fc} / \mathrm{FC}^{+}\right)$. Photoelectron spectroscopy in air (PESA) measurements were recorded using a Riken Keiki PESA spectrometer (Model AC-2) with power settings of $20 \mathrm{nW}$. Final compounds were purified on a JAI size-exclusion recycling HPLC equipped with 2 and $2.5 \mathrm{H}$ columns mounted in series.

Compound 3: Cyanoacetic acid (408 mg, $4.8 \mathrm{mmol}$ ), 2 (502 $\mathrm{mg}, 0.4 \mathrm{mmol})$, EDC (1.01 g, $5.3 \mathrm{mmol})$ and DMAP (673 $\mathrm{mg}, 5.5 \mathrm{mmol}$ ) were placed in a Schlenk tube under an inert atmosphere and anhydrous dichloromethane (5 $\mathrm{mL}$ ) was added. The reaction mixture was then heated under reflux for $6 \mathrm{~h}$. Once at room temperature, the organic layer was washed with $\mathrm{HCl}(1 \mathrm{M})(2 \times 10 \mathrm{~mL})$, water $(2 \mathrm{x}$ $10 \mathrm{~mL}$ ), dried with $\mathrm{MgSO}_{4}$ and the solvent was removed under reduced pressure using a rotary evaporator to afford $616 \mathrm{mg}$ of compound 3 as a yellow oil (85\% yield). IR (neat): $v=2083 \mathrm{~cm}^{-1}(\mathrm{C}=\mathrm{N}), 1737 \mathrm{~cm}^{-1}(\mathrm{C}=\mathrm{O}), 1179 \mathrm{~cm}^{-1}$ $\left(\mathrm{Csp}^{3}-\mathrm{O}\right) .{ }^{1} \mathrm{H}$ NMR $\left(500 \mathrm{MHz}, \mathrm{DMSO}-d_{6}\right): \delta 4.26\left(\mathrm{t},{ }^{3} \mathrm{~J}_{\mathrm{H}, \mathrm{H}}=\right.$ $7.0 \mathrm{~Hz}, 16 \mathrm{H}), 4.03(\mathrm{~s}, 16 \mathrm{H}), 2.79\left(\mathrm{t},{ }^{3} \mathrm{~J}_{\mathrm{H}, \mathrm{H}}=7.0 \mathrm{~Hz}, 16 \mathrm{H}\right)$, $2.66(\mathrm{~m}, 16 \mathrm{H}), 1.04(\mathrm{~m}, 16 \mathrm{H}) .{ }^{13} \mathrm{C}\left\{{ }^{1} \mathrm{H}-\mathrm{NMR}(125 \mathrm{MHz}\right.$, DMSO- $\left.d_{6}\right)$ : $\delta 164.3,115.0,64.6,29.1,25.3,24.3,12.4$. ${ }^{29} \mathrm{Si}\left\{{ }^{1} \mathrm{H}\right\}-N M R$ (99 MHz, DMSO- $d_{6}$ ): $\delta$-68.5. MS (MALDITOF $\left.^{+}, \mathrm{dit}^{+}\right) \mathrm{m} / \mathrm{z}: 1815.1\left[\mathrm{M}^{+}\right]$.

EA-POSS: A microwave flask was charged with POSS 3 (90 mg, $50.2 \mu \mathrm{mol})$, aldehyde 5 (355 mg, $0.6 \mathrm{mmol}$ ) and $\mathrm{CHCl}_{3}(10 \mathrm{~mL})$ before being sealed and deaerated by means of argon bubbling. Then two drops of triethylamine were added, and the mixture was irradiated in the microwave reactor at $120{ }^{\circ} \mathrm{C}$. After $2 \mathrm{~h}$ of reaction, the crude was cooled down, the solvent removed under vacuum and the solid was triturated in $\mathrm{MeOH}$ and filtrated. Thereafter, the resulting mixture was injected in a recycling preparative HPLC. The major fraction was isolated, concentrated and the red solid was recrystallized in a $\mathrm{CH}_{2} \mathrm{Cl}_{2} / \mathrm{MeOH}$ (1:9) mixture affording $200 \mathrm{mg}$ of the target compound as a red solid ( $63 \%$ yield). Additionally, $82 \mathrm{mg}$ of aldehyde 5 were recovered through the HPLC purification. IR (neat): $v=3026 \mathrm{~cm}^{-1}(\mathrm{Csp}-\mathrm{H}, \mathrm{Ar})$, 2963$2852 \mathrm{~cm}^{-1}$ ( $\left.\mathrm{Csp}^{3}-\mathrm{H}\right), 2220 \mathrm{~cm}^{-1}(\mathrm{C} \equiv \mathrm{N}), 1722 \mathrm{~cm}^{-1}(\mathrm{C}=\mathrm{O})$, $1589-1432 \mathrm{~cm}^{-1}$ (C=C, Ar), $1184 \mathrm{~cm}^{-1}\left(\mathrm{Csp}^{3}-\mathrm{O}\right), 1051 \mathrm{~cm}^{-1}$ $\left(\mathrm{Csp}^{3}-\mathrm{N}\right) .{ }^{1} \mathrm{H}-\mathrm{NMR}\left(300 \mathrm{MHz}, \mathrm{CDCl}_{3}\right): \delta 8.20(\mathrm{~m}, 8 \mathrm{H}), 7.63$ - $7.50(\mathrm{~m}, 40 \mathrm{H}), 7.46\left(\mathrm{~d},{ }^{3} \mathrm{~J}_{\mathrm{H}, \mathrm{H}}=8.6 \mathrm{~Hz}, 32 \mathrm{H}\right), 7.39(\mathrm{~m}$, $48 \mathrm{H}), 7.31\left(\mathrm{~d},{ }^{3} \mathrm{~J}_{\mathrm{H}, \mathrm{H}}=7.2 \mathrm{~Hz}, 16 \mathrm{H}\right), 7.21\left(\mathrm{~d},{ }^{3} \mathrm{~J}_{\mathrm{H}, \mathrm{H}}=3.9 \mathrm{~Hz}\right.$, $8 \mathrm{H}), 7.13(\mathrm{~m}, 32 \mathrm{H}), 7.09-7.03(\mathrm{~m}, 16 \mathrm{H}), 4.43\left(\mathrm{t},{ }^{3} \mathrm{~J} \mathrm{H,H}=\right.$ $7.2 \mathrm{~Hz}, 16 \mathrm{H}), 2.89\left(\mathrm{t},{ }^{3} \mathrm{~J}_{\mathrm{H}, \mathrm{H}}=7.2 \mathrm{~Hz}, 16 \mathrm{H}\right), 2.80\left(\mathrm{t},{ }^{3} \mathrm{~J}_{\mathrm{H}, \mathrm{H}}=\right.$ $8.2 \mathrm{~Hz}, 16 \mathrm{H}), 1.15\left(\mathrm{t},{ }^{3} \mathrm{~J}_{\mathrm{H}, \mathrm{H}}=8.4 \mathrm{~Hz}, 16 \mathrm{H}\right) .{ }^{13} \mathrm{C}\left\{{ }^{1} \mathrm{H}\right\}-\mathrm{NMR}$ $\left(75 \mathrm{MHz}, \mathrm{CDCl}_{3}\right): \delta 162.9,148.1,147.7,146.6,146.5$, $146.4,140.5,139.9,136.3,134.0,128.9,128.1,127.8$, $127.4,127.1,126.8,125.0,124.1,123.6,123.5,116.1$, 96.7, 65.0, 30.1, 26.5, 13.2. ${ }^{29} \mathrm{Si}\left\{{ }^{1} \mathrm{H}\right\}-\mathrm{NMR}(59.6 \mathrm{MHz}$, $\mathrm{CDCl}_{3}$ ): $\delta$ - 68.9. MS (MALDI-TOF+, dit $^{+}$) m/z: $6368.2[\mathrm{M}+]$. 
Device characterization and testing: Indium tin oxide (ITO) pre-coated glass slides of $24 \times 25 \times 1.1 \mathrm{~mm}$ with a sheet resistance of $\mathrm{RS}=7 \Omega / \mathrm{sq}$ were purchased from Visiontek Systems LTD. The substrates were washed with a diluted Deconex ${ }^{\circledR} 12$ PA-x solution ( $2 \%$ in water) and scrubbed using dishwashing soap before being cleaned by a series of ultrasonic treatments in distilled water $\left(15.3 \mathrm{M} \Omega \mathrm{cm}^{-1}\right)$, acetone and isopropanol for $15 \mathrm{~min}$ each. Once dried under a steam of nitrogen, a UV-ozone plasma treatment (UV/Ozone ProCleaner Plus, Bioforce Nanosciences) was performed for $15 \mathrm{~min}$. An aqueous solution of poly(3,4ethylenedioxy-thiophene):poly(styrenesulfonate)

(PEDOT:PSS; Ossila), filtered through a $0.45 \mu \mathrm{m} \mathrm{RC}$ membrane (Millex $\AA$ ), was spun-cast onto the patterned ITO surface at $6000 \mathrm{rpm}$ for $40 \mathrm{~s}$ before being baked at 140 ${ }^{\circ} \mathrm{C}$ for $30 \mathrm{~min}$. Then, blends of EA-POSS and PC $\mathbf{~}_{61} \mathrm{BM}$ or $\mathbf{P C}_{71} \mathbf{B M}$ at different weight to weight ratios were dissolved in chloroform at a total concentration of $10 \mathrm{mg} \mathrm{mL}^{-1}$, stirred at $30{ }^{\circ} \mathrm{C}$ for 30 minutes and spun-cast at $1500 \mathrm{rpm}$ onto the PEDOT:PSS layer. Finally, devices were completed by the successive thermal deposition of $\mathrm{Ca}(7 \mathrm{~nm})$ and aluminium $(100 \mathrm{~nm})$ at a pressure of $1.5 \times 10^{-6}$ Torr through a shadow mask defining six cells of $27 \mathrm{~mm}^{2}$ each $(13.5 \mathrm{~mm}$ x $2 \mathrm{~mm}$ ). J-V curves were recorded using a Keithley 236 source-measure unit and a home-made acquisition program. The light source was an AM1.5 Solar Constant 575 PV simulator (Steuernagel Lichttecknik, equipped with a metal halogen lamp). The light intensity was measured by a broad-band power meter (13PEM001, Melles Griot). Atomic Force Microscopy (AFM) experiments were performed using the Nano-Observer microscope from CS Instrument. The topographic images were obtained in tapping mode. Images were processed using Gwyddion SPM data analysis software. Optimized blends were spun cast on the above described PEDOT:PSS modified ITO substrates. Gold electrodes $(100 \mathrm{~nm})$ were subsequently and thermally evaporated under a vacuum of $1.5 \times 10^{-5}$ Torr, through a shadow mask defining actives area of 10 $\mathrm{mm}^{2}, 5 \mathrm{~mm}^{2}, 1.5 \mathrm{~mm}^{2}$ and $0.8 \mathrm{~mm}^{2}$ per substrates. Hole mobilities $\mu \mathrm{h}$ were evaluated using the Mott-Gurney law, ie, $\mathrm{JsCLC}=(9 / 8) \varepsilon_{0} \varepsilon r \mu \mathrm{e}\left(\mathrm{V}^{2} / \mathrm{d}^{3}\right)$ where $\varepsilon r$ is the static dielectric constant of the medium $(\varepsilon r=3)$ and $d$, the thickness of the active layer.

\section{Results \& discussion}

The synthetic route to prepare the target electro-active POSS EA-POSS derivative is illustrated in Scheme 1.

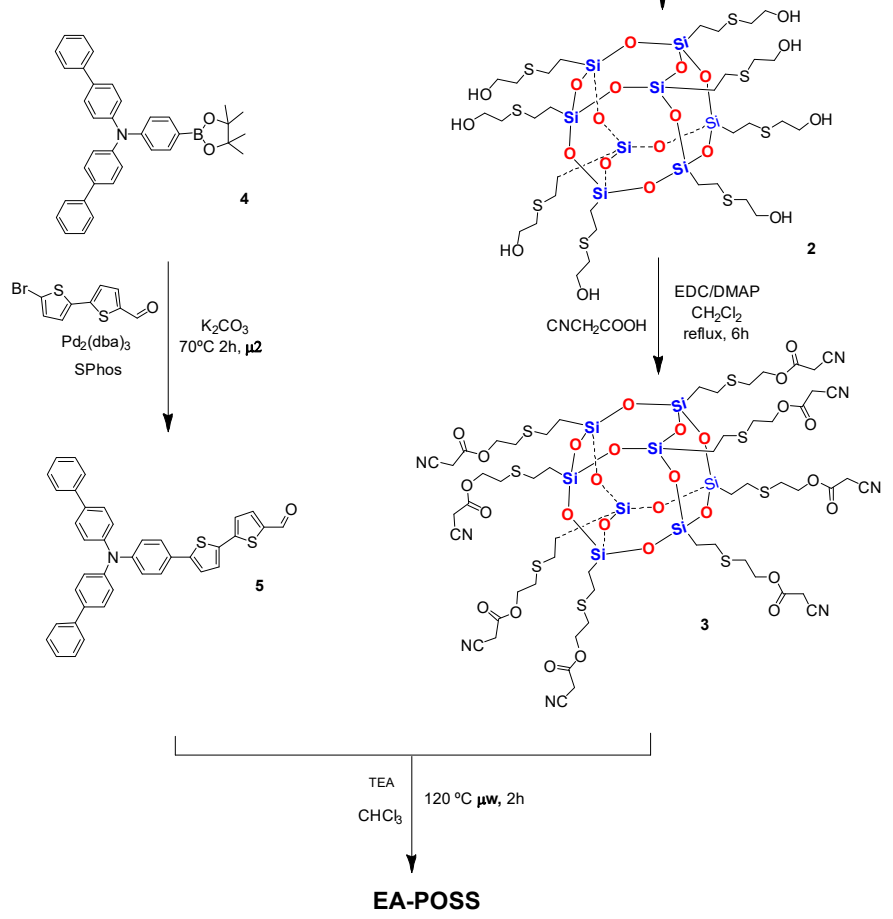

Scheme 1. Synthesis of the POSS-containing octamer EA-POSS.

First, a thiol-ene click reaction between the octavinyl POSS 1 and $\beta$-mercaptoethanol was performed to afford the octa(2-hydroxyethylthioethyl) polyhedral oligomeric silsesquioxane 2 that was subsequently engaged into a Steglich esterification reaction with cyanoacetic acid. In parallel, the complementary intermediate $\mathbf{5}$ was prepared by a microwave assisted Suzuki reaction between the commercially available boronic arylamine 4 and the 5'bromo-[2,2'-bithiophene]-5-carbaldehyde. Finally, 3 and $\mathbf{5}$ were engaged in a Knoevenagel condensation, also performed under microwave irradiation, to afford the fully substituted core in a reduced period of time. Instead of performing a conventional purification on silica gel or through a Soxhlet extraction (without guarantying their effectiveness), it was decided to inject the crude into a sizeexclusion recycling HPLC (Figure 2). As depicted in Figure 2 , three fractions were successfully collected. 


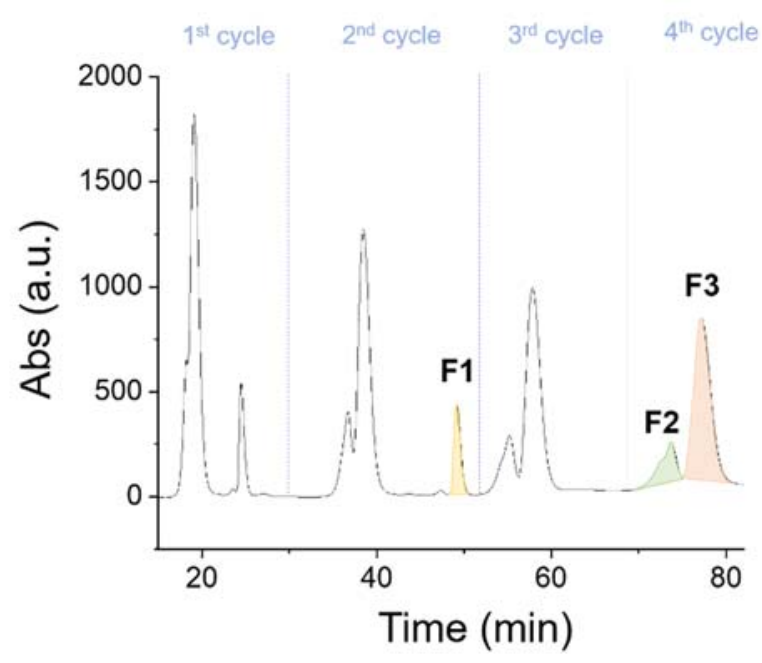

Figure 2. Chromatogram profile obtained by UV-vis spectrometric detection after injection of the EA-POSS crude in the sizeexclusion recycling preparative HPLC.

While fraction F1 corresponds to compound $\mathbf{5}$, introduced in excess to favor the reaction, the exact composition of F2 still remains unclear. However, a mass analysis of the major fraction, namely $\mathrm{F} 3$, revealed the presence of a single molecular structure with a molecular weight of 6369 g. $\mathrm{mol}^{-1}$, thus corresponding to the target octamer, namely EA-POSS (see SI). Once isolated with a decent yield after a final recrystallization (63\%), the latter was characterized by UV-Visible absorption spectroscopy (Figure 3). As expected, two main bands, characteristic of the push-pull moieties were recorded at ca $350 \mathrm{~nm}$ and $494 \mathrm{~nm}$, attributed to $\pi-\pi^{*}$ and internal charge transfer (ICT) transitions respectively. ${ }^{22}$

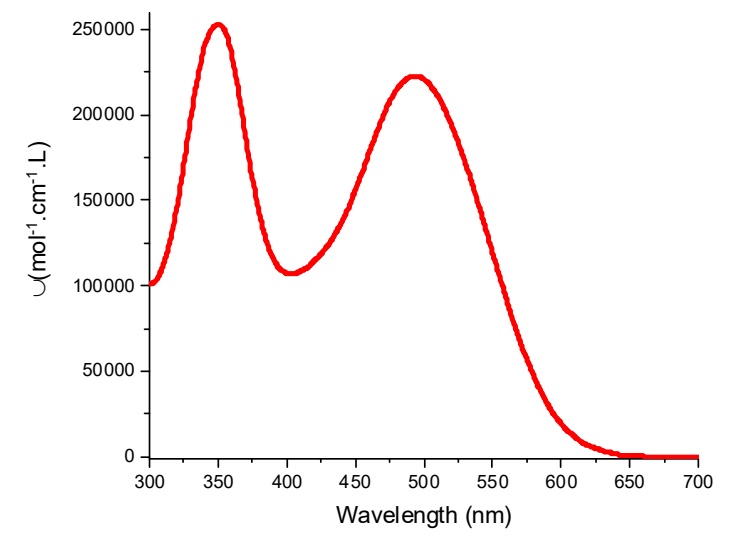

Figure 3. UV-Vis absorption spectra of EA-POSS in diluted dichloromethane solutions (ca. $10^{-5} \mathrm{M}$ ).

Cyclic voltammetry was then conducted in a $0.1 \mathrm{M}$ solution of tetrabutylammonium hexafluorophosphate $\left(\mathrm{Bu}_{4} \mathrm{NPF}_{6}\right)$ solubilized in dichloromethane. It turns out that two oxidation processes, attributed to the successive formation of a stable radical cation and dication on the push-pull derivatives, were observed at $\mathrm{E}_{\mathrm{pa} 1} \approx 0.45 \mathrm{~V}$ and $\mathrm{E}_{\mathrm{pa}} 2 \approx$ $0.89 \mathrm{~V}$ vs. Fc/Fc ${ }^{+}$(Figure 4).

a)

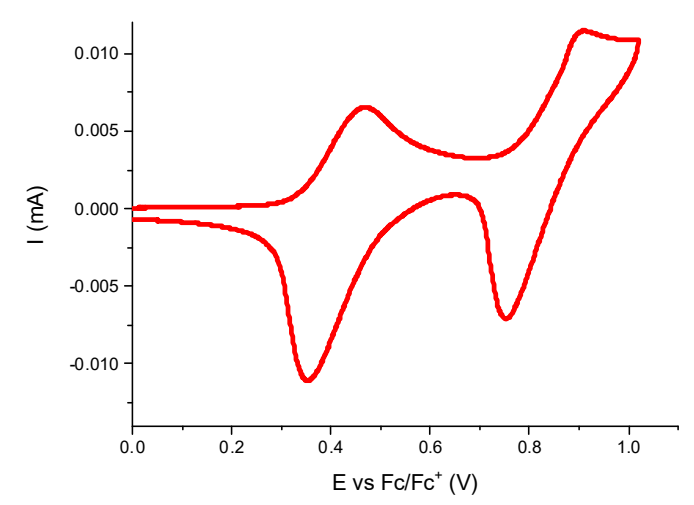

b)

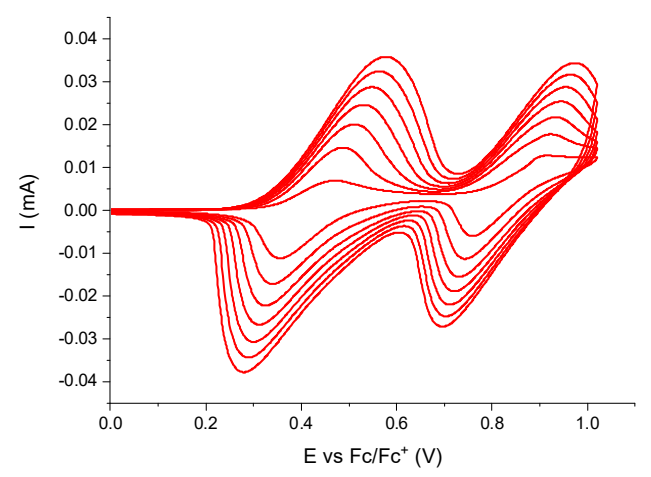

Figure 4. a) Cyclic voltammograms of EA-POSS and b) electrodeposition of EA-POSS upon cycling in the following conditions: $5 \mathrm{mM}$ in 0.1 $\mathrm{M} \mathrm{Bu}_{4} \mathrm{NPF}_{6} / \mathrm{CH}_{2} \mathrm{Cl}_{2}$ recorded at $100 \mathrm{mV} . \mathrm{s}^{-1}$

Interestingly, the super imposition of successive cyclic voltammograms of EA-POSS revealed a propensity to form electrodeposited thin films on the surface of the working electrode. Estimated at ca $-5.21 \mathrm{eV}$ from the onset of the first oxidation process, its highest occupied molecular orbital (HOMO) level was found to be slightly deeper $(-5.58 \mathrm{eV})$ once spun cast on a glass sheet and measured by photoelectron spectroscopy in air (see $\mathrm{SI}$ ). These thin films were also used to determine the optical band gap of EA-POSS in solid state (ca $1.96 \mathrm{eV}$ ), enabling the estimation of its LUMO level $(-3.62 \mathrm{eV})$ and revealing its electronic compatibility with fullerene derivatives. Consequently, the potential of this decorated POSS derivative as donor material was thereafter evaluated through the fabrication of basic air-processed bulk heterojunction solar cells. To that end, the well-known $\mathbf{P C}_{61} \mathbf{B M}$ was first used as the complementary electron acceptor material. It turned out that power conversion efficiencies (PCEs) up to $1.4 \%$ were reached for a $1: 2$ donor-acceptor weight-to-weight blend ratio deposited from a chloroform solution (Table S1). Current density- 
voltage $(\mathrm{J}-\mathrm{V})$ curves of the best device are plotted in Figure $5 \mathrm{a}$ and the corresponding photovoltaic data are gathered in Table 1.

a)

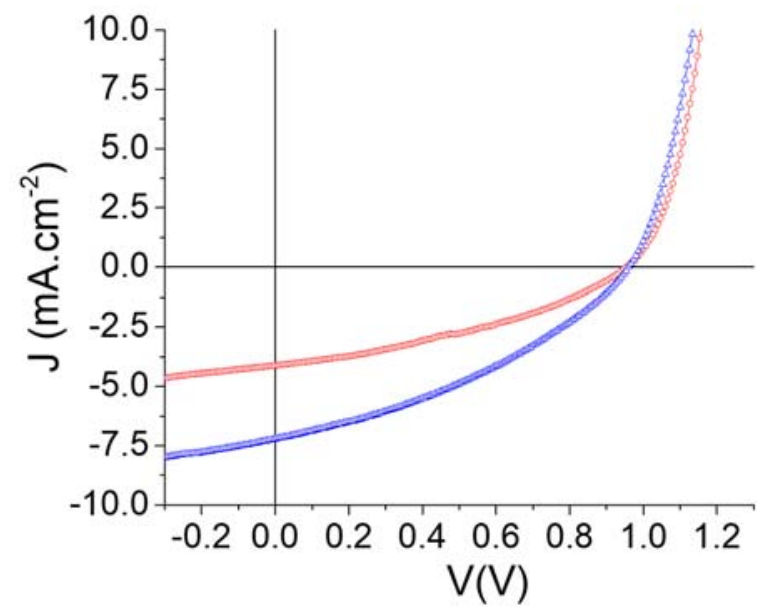

b)

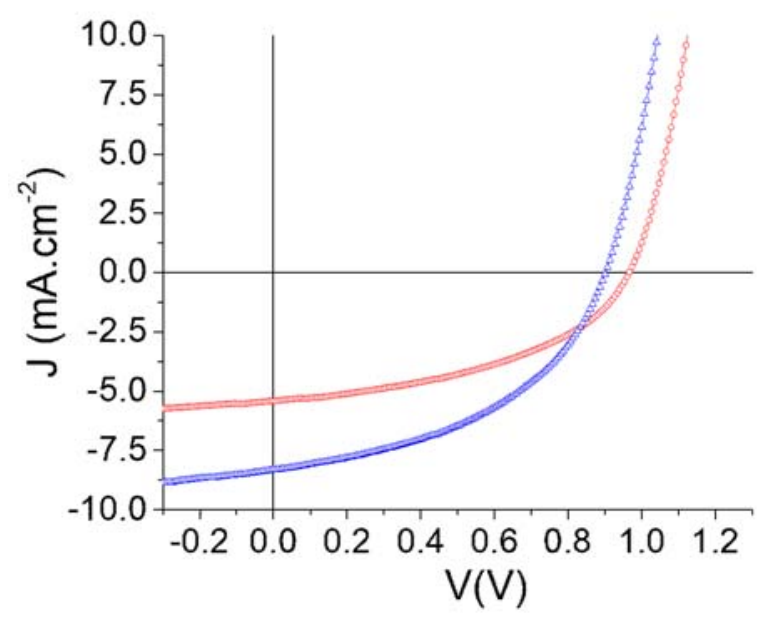

Figure 5. J-V characteristics of the best solar cells based on a blend of EA-POSS with $\mathbf{P C}_{61} \mathbf{B M}$ (red) and $\mathbf{P C}_{71} \mathbf{B M}$ (blue) before (A) and after $(B)$ a thermal treatment at $90^{\circ} \mathrm{C}$ for $5 \mathrm{~min}$.

As so often, efficiencies were significantly improved by replacing the $\mathbf{P C}_{61} \mathbf{B M}$ by the $\mathrm{PC}_{71} \mathrm{BM}$. With similar hole mobilities of ca $3.3 \times 10^{-4} \mathrm{~cm}^{2} \mathrm{~V}^{-1} \mathrm{~s}^{-1}$ measured for both blends via the space charge limited currents (SCLC) methods (Figure S13), this difference mainly comes from a better contribution of the $\mathrm{C}_{70}$ derivative to the photocurrent (Figure S14) resulting in higher short circuit currents $\left(\mathrm{J}_{\mathrm{sc}}\right)$ (7.21 mA.cm ${ }^{-2}$ vs $\left.4.11 \mathrm{~mA} . \mathrm{cm}^{-2}\right)$ and therefore PCE $(2.50 \%$

vs $1.44 \%)$. On the other hand, while annealings are usually deleterious for discrete push-pull based bulk heterojunctions solar cells, post thermal treatments were found to be beneficial, to some extent, for both EA-POSS / fullerene blends (Figure $5 \mathrm{~b}$ and Figure S15-16). With moderate impacts on the open circuit voltage (slight decrease for $\mathbf{P C}_{71} \mathbf{B M}$ based devices), a mild thermal annealing up to $90^{\circ} \mathrm{C}$ indeed positively affects both the Jsc and fill-factors (FF). As a result, promising maximum PCEs of $2.35 \%$ and $3.41 \%$ were reached for the $\mathbf{P C}_{61} \mathbf{B M}$ and $\mathrm{PC}_{71} \mathrm{BM}$ based active layers respectively (Table 1 ). To gain further insights into these features, atomic force microscopy (AFM) measurements were performed on annealed and non-annealed champion devices (Figure 6).

EA-POSS/PC ${ }_{61}$ BM

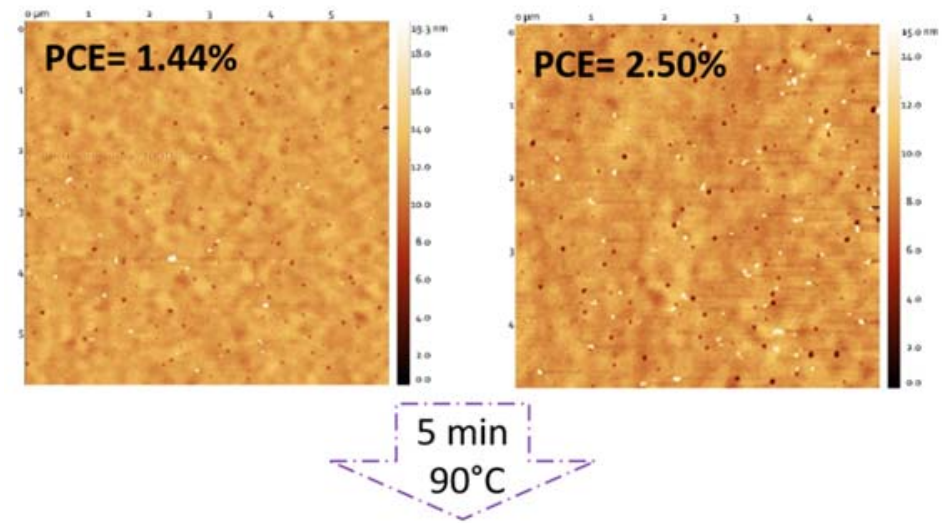

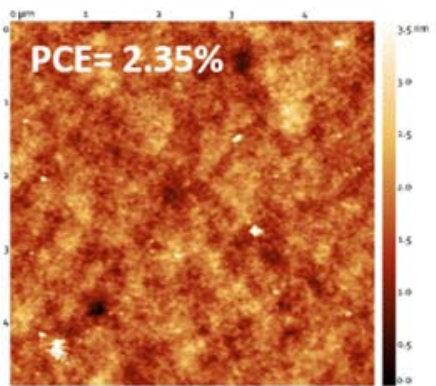

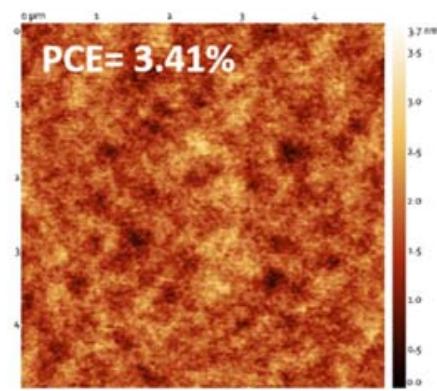

Figure 6. AFM phase images of optimized blends before (top) and after thermal annealing (bottom).

Interestingly, as cast active layers both show similar patterns with nanometric cavities of 2-6 $\mathrm{nm}$ depth homogeneously distributed over the surfaces. It turned out that annealing the samples induces a complete vanishing of the latter resulting in smooth and homogenous surfaces (root mean square values $<0.5 \mathrm{~nm}$ ), demonstrating, once again, the drastic, but in this case, beneficial impact of thermal treatments.

Table 1. Photovoltaic characteristics of the best bulk heterojunction cells based on EA-POSS blended with the $P C_{61} B M$ and $\mathrm{PC}_{71} \mathrm{BM}$ in a 1:2 D:A ratio (8 devices fabricated per experimental condition). Measurements performed under an AM. 1.5 simulated solar illumination $\left(100 \mathrm{~mW} \cdot \mathrm{cm}^{-2}\right)$.

\begin{tabular}{|c|c|c|c|c|c|}
\hline Fullerene & $\begin{array}{l}\text { Thermal } \\
\text { treatment }\end{array}$ & $\begin{array}{l}\text { Voc } \\
\text { (V) }\end{array}$ & $\begin{array}{c}\text { Jsc } \\
(\mathrm{mA} \mathrm{cm}-2)\end{array}$ & $\begin{array}{l}\mathbf{F F} \\
(\%)\end{array}$ & $\begin{array}{l}\text { PCE } \\
(\%)\end{array}$ \\
\hline $\mathrm{PC}_{61} \mathrm{BM}$ & $\begin{array}{c}\text { None } \\
5 \mathrm{~min} \text { at } 70^{\circ} \mathrm{C} \\
5 \mathrm{~min} \text { at } 90^{\circ} \mathrm{C} \\
5 \mathrm{~min} \text { at } 110^{\circ} \mathrm{C}\end{array}$ & $\begin{array}{l}0.95 \\
0.96 \\
\mathbf{0 . 9 6} \\
0.92\end{array}$ & $\begin{array}{l}4.11 \\
4.67 \\
5.41 \\
4.67\end{array}$ & $\begin{array}{l}36.67 \\
44.54 \\
44.91 \\
41.53\end{array}$ & $\begin{array}{l}1.44 \\
2.01 \\
2.35 \\
1.78\end{array}$ \\
\hline $\mathrm{PC}_{71} \mathrm{BM}$ & $\begin{array}{c}\text { None } \\
5 \mathrm{~min} \text { at } 70^{\circ} \mathrm{C} \\
5 \mathrm{~min} \text { at } 90^{\circ} \mathrm{C} \\
5 \mathrm{~min} \text { at } 110^{\circ} \mathrm{C}\end{array}$ & $\begin{array}{l}0.96 \\
0.93 \\
0.90 \\
0.86\end{array}$ & $\begin{array}{l}7.21 \\
8.01 \\
8.31 \\
4.67\end{array}$ & $\begin{array}{l}36.05 \\
43.07 \\
45.56 \\
42.38\end{array}$ & $\begin{array}{l}2.50 \\
3.20 \\
3.41 \\
1.70\end{array}$ \\
\hline
\end{tabular}




\section{Conclusions}

In summary, we report herein the synthesis, characterization and use of the first molecular electro active POSS derivative as donor material in organic solar cells. Decorated with eight simple arylamine-based pushpull building-blocks, promising power conversion efficiencies up to $2.5 \%$ and $3.4 \%$ were reached once blended with the commonly used $\mathbf{P C}_{61} \mathbf{B M}$ and $\mathbf{P C}_{71} \mathbf{B M}$ respectively. Considering that this proof of concept was achieved with an electro active dye limited in term of absorption range in the visible (350-550 $\mathrm{nm}$ ), the synthetic accessibility and tunability of such octamer architectures clearly open doors to new panchromatic design principles. Moreover, with good solubility, processability and film forming properties, multimer structures contribute in bridging the gap between small molecules and polymers.

\section{Conflicts of interest}

There are no conflicts to declare.

\section{Acknowledgements}

Authors thank the MATRIX SFR of the University of Angers. J.M.A.C. and P.S.M. thanks the European Union's Horizon 2020 research and innovation program under Marie Sklodowska Curie Grant agreement No.722651 (SEPOMO). The Région Pays de la Loire is also acknowledged for the Projet «étoile montante SAMOA».

\section{Notes and references}

1. Y. Cui, H. Yao, J. Zhang, K. Xian, T. Zhang, L. Hong, Y. Wang Y. Xu, K. Ma, C. An, C. He, Z. Wei, F. Gao and J. Hou, Adv. Mater., 2020, 32, 1908205.

2. P. Meredith, W. Li and A. Armin, Advanced Energy Materials, 2020, 10, 2001788.

3. H. Sun, F. Chen and Z.-K. Chen, Materials Today, 2019, 24, 94-118.

4. H. Gaspar, F. Figueira, L. Pereira, A. Mendes, J. C. Viana and G. Bernardo, Materials (Basel, Switzerland), 2018, 11, 2560.

5. A. Guerrero and G. Garcia-Belmonte, Nano-Micro Letters, 2016, 9, 10.

6. R. S. Gurney, D. G. Lidzey and T. Wang, Rep. Prog. Phys. 2019, 82, 036601.

7. A. Wadsworth, M. Moser, A. Marks, M. S. Little, N. Gasparini, C. J. Brabec, D. Baran and I. McCulloch, Chem. Soc. Rev., 2019, 48, 1596-1625.

8. K. Weng, L. Ye, L. Zhu, J. Xu, J. Zhou, X. Feng, G. Lu, S. Tan, F. Liu and Y. Sun, Nature Communications, 2020, 11, 2855.
9. C.-H. Kim, S.-H. Cha, S. C. Kim, M. Song, J. Lee, W. S. Shin, S.-J. Moon, J. H. Bahng, N. A. Kotov and S.-H. Jin, ACS Nano, 2011, 5, 3319-3325.

10. B. Paci, G. D. Spyropoulos, A. Generosi, D. Bailo, V. R. Albertini, E. Stratakis and E. Kymakis, Adv. Funct. Mater., 2011, 21, 3573-3582.

11. G. D. Spyropoulos, M. M. Stylianakis, E. Stratakis and E. Kymakis, Appl. Phys. Lett., 2012, 100, 213904.

12. H. Shen, N. E. Valadez-Pérez, B. Guralnick, Y. Liu and M. E. Mackay, J. Mater. Chem. C, 2014, 2, 10087-10100.

13. M. Garg and V. Padmanabhan, Scientific Reports, 2016, 6, 33219.

14. Z. Li, J. Kong, F. Wang and C. He, J. Mater. Chem. C, 2017, 5, 5283-5298.

15. J. Wu and P. T. Mather, Polymer Reviews, 2009, 49, 25-63.

16. W.-B. Zhang, Y. Tu, H.-J. Sun, K. Yue, X. Gong and S. Z. D. Cheng, Science China Chemistry, 2012, 55, 749-754.

17. K. Ueda, K. Tanaka and Y. Chujo, Polym. J., 2016, 48, 11331139.

18. Q. Wu, M. Bhattacharya and S. E. Morgan, ACS Applied Materials \& Interfaces, 2013, 5, 6136-6146.

19. T. Zhu, L. Zheng, C. Yi, T. Yu, Y. Cao, L. Liu and X. Gong, ACS Applied Electronic Materials, 2019, 1, 1458-1464.

20. X. Gong, C. Soci, C. Yang, A. J. Heeger and S. Xiao, J. Phys. D: Appl. Phys., 2006, 39, 2048-2052.

21. R.-H. Lee and H.-H. Lai, Eur. Polym. J., 2007, 43, 715-724.

22. P. S. Marqués, J. M. Andrés Castán, P. Josse, M. Blais, A. H. Habibi, I. Ramirez, K. Walzer, J. Roncali, P. Blanchard and C. Cabanetos, New J. Chem., 2020, 44, 11441-11447.

23. A. Labrunie, P. Josse, S. Dabos-Seignon, P. Blanchard and C. Cabanetos, Sustainable Energy \& Fuels, 2017, 1, 19211927.

$24 . \quad$ L. Wang, C. Zhang, H. Cong, L. Li, S. Zheng, X. Li and J. Wang, The Journal of Physical Chemistry B, 2013, 117, 8256-8268. 